Bartosz Atroszko

https://doi.org.10.26881/ae.2020.17.01

ORCID: 0000-0001-8265-1103

Uniwersytet Gdański

Pawet Andrzej Atroszko

ORCID: 0000-0001-5707-3882

Uniwersytet Gdański

\title{
Presja edukacyjna a rozwój uzależnienia od uczenia się, uzależnienia od pracy oraz innych zaburzeń psychicznych
}

„Krzycz na całe gardło, nie przestawaj! Podnoś głos twój jak trąba!”

Księga Izajasza 58,1

„Było to więc dla młodzieży torturą: gdy się ją przez sześć, siedem, osiem godzin dziennie zajmowało publicznymi lekcjami i ćwiczeniami, a nadto jeszcze kilka godzin - prywatnymi; gdy się ją przeciążało koniecznością wyuczania się dyktowanych wykładów, obowiązkowym opracowywaniem ćwiczeń i pamięciowym opanowywaniem jak największej ilości materiału, aż do mdłości, a nawet, jak to nieraz widzimy, do wariacji”.

Jan Amos Komeński, XVII-wieczny pedagog uważany za ojca nowożytnej edukacji

„Ojciec był maklerem, a mama lawyerem

I grube portfele, co chudły wraz z nim na odwykach".

Mata, Patointeligencja

\section{Wprowadzenie}

Pierwszym krokiem do skutecznej prewencji lub terapii zaburzeń psychicznych jest rozpoznanie istnienia problemu. Psychopatologia i jej ekstremalne konsekwencje, na przykład w postaci samobójstw, wśród młodych pokoleń w Polsce rośnie od dekad. Bez realnego dialogu społecznego, bez wsłuchania się w głosy dzieci i młodzieży, bez poważnego traktowania ich potrzeb i poszanowania dla ich emocji, bez opinii specjalistów i systematycznych badań naukowych nie jesteśmy w stanie rozpoznać przyczyn tego zjawiska. Co gorsza - do dziś nie istnieją żadne realne 
i systematyczne działania zapobiegające pogarszaniu się stanu zdrowia psychicznego młodych Polaków i zmierzające do jego zrozumienia.

Ważne znaczenie w obserwowanych zmianach w zakresie dobrostanu omawianej grupy mogą mieć społeczne i gospodarcze transformacje zachodzące w ostatnich dekadach w Polsce. W artykule wskazano w szczególności na dynamiczny rozwój gospodarczy i związane z nim przemiany na rynku pracy i w organizacji szkolnictwa, których nierozpoznanym kosztem może być pogorszenie się zdrowia psychicznego polskiej populacji, zwłaszcza najmłodszych. Obserwacja ta w żaden sposób nie sugeruje, że rozwój gospodarczy czy gospodarka wolnorynkowa są szkodliwe in se, ale że niepohamowane dążenie do rozwoju gospodarczego jako celu samego w sobie, bez uwzględnienia ludzkich potrzeb i możliwości, paradoksalnie skutkuje pogorszeniem się dobrostanu na poziomie populacyjnym. Zjawisko to jest dobrze udokumentowane między innymi wśród obywateli najdynamiczniej rozwijających się krajów azjatyckich. Obserwuje się wzrost zgonów (w tym samobójstw) związanych z nadmiernym obciążeniem pracą (Tsui 2008), które są skutkiem na przykład wzrastających wymagań dotyczących efektywności pracowników, konkurencji, globalizacji i niestabilności zatrudnienia (Idris, Dollard, Winefield 2011). Wymogi rynku pracy bezpośrednio i pośrednio wpływają na system szkolnictwa. Jest on w coraz większym stopniu organizowany według podobnej logiki (na temat ekonomizacji edukacji zob. Szkudlarek 2005), w ramach której uczniowie i ich rzeczywistość są ujmowani za pomocą zdehumanizowanego języka wskaźników (Melosik 2016). Prowadzi to do nadmiernej presji edukacyjnej związanej z wąsko rozumianymi kryteriami skuteczności i osiągnięć (np. wynikami na standaryzowanych testach). Dorota Klus-Stańska (2017) nazwała to obrazowo „walką o testo-maniakalne przetrwanie”. Jedną z dobrze udokumentowanych konsekwencji funkcjonowania w niestabilnym środowisku pełnym presji i zagrożeń przekraczających możliwości adaptacyjne człowieka jest rozwój uzależnień od substancji i zachowań jako formy radzenia sobie z nadmiernym stresem (Goeders 2003; Sinha 2007; Tavolacci et al. 2013).

Celem niniejszego artykułu jest przedstawienie potencjalnych związków łączących presję edukacyjną odczuwaną przez uczniów i studentów z rozwojem zaburzeń psychicznych - między innymi uzależnienia od uczenia się i pracy. Omówione zostaną dwie strony tego samego problemu: pierwszą są próby adaptacji do - w znacznym stopniu zdehumanizowanego - systemu edukacji i organizacji pracy zawodowej (kończące się nieprzystosowaniem, marginalizacją społeczną itd.), a drugą są nadmierne wysiłki, aby powyższy cel osiągnąć, kosztem zdrowia fizycznego, psychicznego, relacji międzyludzkich i - paradoksalnie - produktywności (będące kompulsywnym przeciążaniem się pracą konceptualizowanym jako uzależnienie od niej, a wśród uczniów i studentów jako uzależnienie od uczenia się). Punktem wyjścia przedstawionych rozważań jest rozumienie procesu uzależnienia (ugruntowane w literaturze naukowej) jako ściśle związanego z nieskutecznymi próbami radzenia sobie z nadmiernym stresem. Zarówno niepowodzenie w tej adaptacji, jak i nadmierne wysiłki w celu przystosowania prowadzą do wielu zaburzeń zdrowia 
fizycznego i psychicznego (lęk, depresja, nadużywanie substancji psychoaktywnych i uzależnienia itd.).

W artykule przedstawiono związki między presją edukacyjną a zaburzeniami psychicznymi i zjawiskami z obszaru psychopatologii (np. samobójstwa), przeprowadzono analizę aktualnego stanu wiedzy na temat uzależnienia od pracy oraz uczenia się, a także omówiono podobieństwa i różnice między zaangażowaniem w daną aktywność (pracę lub naukę) a uzależnieniem od niej.

Destrukcyjny wpływ nauki szkolnej nie jest w polskiej pedagogice zagadnieniem nowym. Można wręcz zaryzykować stwierdzenie, że stanowi on niejako leitmotiv współczesnej myśli o wychowaniu i kształceniu. Szczególnie jest on eksplorowany przez badaczy o orientacji krytycznej. Podobnie problematyka zdrowotnych konsekwencji przeciążenia nauką - w tym ekstremalnych, takich jak śmierć (The New York Times 1900) i samobójstwa (Zeng, Le Tendre 1998) - jest dobrze udokumentowana $\mathrm{w}$ literaturze naukowej. Pierwsze wzmianki na ten temat sięgają zarania nowożytnych systemów edukacji (zob. Komeński 1956).

Niniejsze rozważania można traktować jako głos w dyskusji na temat tego, jaki rzeczywisty (a nie zakładany) wpływ na uczniów wywiera polski system szkolnictwa i dominujący w nim model kształcenia, jakiego rodzaju absolwentów „produkuje” szkoła i jakiego rodzaju doświadczenia wynoszą z niej młodzi ludzie (zob. Melosik 2016; Klus-Stańska 2017; Kwieciński 1992; Śliwerski, Kobierski 2008). Novum w niniejszym artykule stanowi użycie pojęć i kategorii psychologii klinicznej związanych z uzależnieniami behawioralnymi. Specyfika uzależnienia od uczenia się i od pracy polega na tym, że ich przedmiotem są aktywności powszechnie uznawane za pożyteczne społecznie, godne szacunku i warte propagowania wśród młodzieży - w przeciwieństwie do szkodliwych czy niebezpiecznych (jak np. uzależnienia od pornografii, hazardu, gier komputerowych itd.). Badania nad tymi uzależnieniami - zwłaszcza od uczenia się - stanowią wyzwanie i być może punkt zwrotny w społecznej i ekonomicznej konceptualizacji produktywności. Pokazują one bowiem, że istniejące systemy regulujące szkolnictwo i rynek pracy generują (oprócz niewymiernego ludzkiego cierpienia) olbrzymie straty nie tylko poprzez niszczenie kapitału ludzkiego w grupie osób mających trudności z asymilacją (m.in. dzieci ze środowisk o niskim statusie socjoekonomicznym, dyslektyków czy osób z zespołem nadpobudliwości psychoruchowej z deficytem uwagi, czyli ADHD), ale również wśród niebagatelnej części osób, nierzadko bardzo zdolnych, wkładających nadzwyczajne wysiłki, by się zaadoptować i być produktywnymi. Należy przy tym podkreślić, że osoby, u których zdiagnozowano ADHD czy dysleksję, nierzadko są bardzo zdolne (Bogdanowicz, Adryjanek 2008), ich funkcjonowanie poznawcze jest zróżnicowane (Hoogman et al. 2020; Chamberlain et al. 2018; Gilger, Allen, Castillo 2016), a ich problemy adaptacyjne wynikają często z braku dostosowania systemu szkolnictwa do specyfiki ich funkcjonowania, potrzeb i atutów. Nieoptymalna organizacja szkolnictwa i rynku pracy może skutkować tym, że aktywności, które cenimy społecznie najbardziej (praca i nauka), mogą 
być równie, a być może nawet bardziej destruktywne na poziomie populacyjnym niż zjawiska społecznie piętnowane, takie jak zachowania związane z zażywaniem substancji psychoaktywnych, hazardem, grami komputerowymi czy pornografią (P.A. Atroszko 2018, 2019a).

Artykuł został opracowany na podstawie analizy danych zastanych (desk research). Ich źródłem były polskie i zagraniczne publikacje naukowe dotyczące głównie uzależnienia od pracy i uczenia się oraz związku presji edukacyjnej i funkcjonowania systemu edukacji z psychopatologią, źródła historyczne, raporty międzynarodowych organizacji (WHO, UNICEF), a także raporty i sprawozdania polskich instytucji publicznych (np. NIK). Inspiracją do napisania tejże publikacji było dostrzeżenie przez autorów wyjątkowo destruktywnej roli presji edukacyjnej wywieranej na uczniach polskich szkół. Jest to problem stojący nie tylko u podłoża uzależnienia od uczenia się, ale też - co stało się jasne w toku analizy danych dotyczących zdrowia psychicznego najmłodszych - wielu innych zjawisk z zakresu psychopatologii, w tym nawet samobójstw dzieci i młodzieży.

\section{Presja edukacyjna a psychopatologia}

Jakość życia dzieci w Polsce jest oceniana jako jedna z najniższych w krajach rozwiniętych gospodarczo (UNICEF 2020). O ile stan zdrowia fizycznego i przejawiane umiejętności najmłodszych Polaków odpowiadają mniej więcej średniej dla krajów Organizacji Współpracy Gospodarczej i Rozwoju i Unii Europejskiej, o tyle poziom ich dobrostanu psychicznego jest szczególnie problematyczny (UNICEF 2020). Należy podkreślić, że sytuacja w innych państwach rozwiniętych również jest daleka od stanu idealnego czy choćby zadowalającego. Samobójstwa, brak satysfakcji z życia, otyłość, niskie kompetencje społeczne i edukacyjne stają się coraz częstszymi problemami dzieci i młodzieży w krajach bogatych. Od wielu lat u dzieci i młodzieży w Polsce obserwuje się rosnącą liczbę zaburzeń i chorób psychicznych (Tabak 2014). Ponieważ dotychczasowy system opieki psychiatrycznej nie był przygotowany na tak gwałtowny przyrost osób potrzebujących pomocy, przestał on być wydolny (Bójko, Maślankiewicz 2020). Zjawisko to nazwano „kryzysem psychiatrii dziecięcej" (Hoss et al. 2020; Murawiec 2020). Polska nie jest jednak wyjątkiem pod tym względem. Rosnący kryzys zdrowia psychicznego, zwłaszcza wśród młodych, obserwuje się w wielu rozwiniętych państwach świata (WHO 2005), podobnie zresztą jak kryzys psychiatrii (Katsching 2010). Szczególnie niepokojącym zjawiskiem jest też rosnący w całej populacji Polski odsetek popełnianych samobójstw (Höfer et al. 2012; Kawecki 2019), w tym również wśród najmłodszych (Bąbik, Olejniczak 2014).

Potencjalnych determinantów problemów psychicznych młodych ludzi jest bardzo wiele (Kieling et al. 2011). Wymienia się w tym kontekście czynniki ryzyka o charakterze biologicznym (uwarunkowania genetyczne, urazy, działanie toksyn, 
choroby przewlekłe, otyłość itd.) oraz psychospołecznym, związane z funkcjonowaniem dziecka w rodzinie, szkole i grupie rówieśniczej (Tabak 2014). Do tej drugiej kategorii należy rozpad więzi rodzinnych (w tym rozwody, separacje i emigracja ekonomiczna jednego lub dwójki rodziców za granicę), brak wsparcia społecznego, upowszechnienie mediów społecznościowych i zagrożeń związanych z nieskrępowanym dostępem dzieci i młodzieży do Internetu (uzależnienia od gier komputerowych, pornografii, telefonów komórkowych, mediów społecznościowych itd.), rosnące tempo życia, niezdrowa dieta (Jośko-Ochojska, Lizończyk 2014; Kazimierska, Kinsner 2019; O’Neil et al. 2014), wysoki poziom nierówności społecznych, większe zaangażowanie czasowe i emocjonalne rodziców w pracę zawodową czy wreszcie brak poczucia bezpieczeństwa socjalnego rodzin (niepewność zatrudnienia, zmiany na rynku pracy, a jednocześnie wysoki poziom zadłużenia rodzin itd.).

Zdecydowanie jednym z najważniejszych czynników stresogennych w życiu młodych ludzi jest szkoła i szkolna edukacja (Talik 2011). Stres szkolny wiąże się z pogorszeniem ich stanu zdrowia (Supranowicz, Wysocki 2010). Jego szczególne nasilenie obserwuje się przy okazji egzaminu dojrzałości (Ogińska-Bulik, Zadworna-Cieślak 2014). Pojęcie stresu szkolnego jest złożone, ponieważ dzieci przeżywają go nie tylko w kontekście wyzwań stawianych przez naukę (ocen, wymagań nauczycieli, sprawdzianów czy egzaminów), ale też na przykład relacji z rówieśnikami czy z nauczycielami (Sikora 2010). Niniejszy artykuł dotyczy przede wszystkim presji edukacyjnej, a więc stresu związanego $\mathrm{z}$ dążeniem do osiągnięcia wąsko definiowanego sukcesu edukacyjnego, rozumianego jako wysoka średnia ocen i wysoki wynik na egzaminach zewnętrznych.

Wiele wskazuje na to, że presja edukacyjna negatywnie wpływa nie tylko na zdrowie, ale nawet życie najmłodszych Polaków. Najwięcej samobójstw osób w wieku 10-19 lat zdarza się w maju (okres wystawiania ocen na zakończenie roku szkolnego), najmniej zaś w miesiącach wakacyjnych: w lipcu i sierpniu (Napieralska et al. 2010). Może to, zdaniem badaczy, sugerować, że jedną z ważniejszych przyczyn samobójstw wśród młodzieży jest stres szkolny (Napieralska et al. 2010). Hipoteza ta jest zgodna z ustaleniami zarówno polskich badaczy (zob. Makara-Studzińska 2013), jak i uczonych z innych państw, którzy wskazują na niepowodzenia szkolne jako ważny czynnik skłaniający najmłodszych do zakończenia swojego życia (Greydanus, Calles 2007; Mishra et al. 2013; Richardson et al. 2005). Chociaż może to się wydawać nieprawdopodobne, dla wielu młodych ludzi sukces edukacyjny jest dosłownie sprawą życia lub śmierci. Ważną funkcję w tym kontekście pełnią wygórowane (być może niemożliwe do zrealizowania) oczekiwania rodzicielskie (Bor et al. 2014; Klinger et al. 2015). Warto zaznaczyć, że nie jest to zjawisko nowe - już w przedwojennej polskiej literaturze naukowej wskazywano, że stres wywołany nauką szkolną jest przyczyną samobójstw (Ziółkowska 2020). Współcześni badacze zwracają uwagę również na szersze spektrum czynników związanych ze środowiskiem szkolnym, które mogą sprzyjać kształtowaniu się myśli samobójczych. Należą do nich odrzucenie przez rówieśników, częste zmiany szkoły, wysokie wymagania nauczycieli 
przy jednoczesnym braku odpowiedniego wsparcia uczniów, bezosobowe relacje z dydaktykami, przemoc szkolna, konflikty z nauczycielami i rówieśnikami, trudności w przyswajaniu wiedzy czy nawet brak zajęć rozwijających zainteresowania (Kołodziej et al. 2020).

Problemem jest to, że część uczniów z różnych powodów nie jest w stanie $\mathrm{w}$ ramach istniejącego systemu osiągnąć oczekiwanego sukcesu edukacyjnego. Przykładowo osoby dotknięte ADHD, dysleksją lub lękiem społecznym (SAD), bądź borykające się z innymi problemami utrudniającymi naukę szkolną, muszą uczestniczyć w rywalizacji z resztą uczniów, będąc niejako na przegranej pozycji. W obecnym systemie wysoka pobudliwość psychoruchowa, trudności w czytaniu czy lęk przed byciem ocenianym przez innych i wystąpieniami publicznymi są konceptualizowane jako deficyty i zaburzenia. Nie ma wątpliwości, że w swojej ekstremalnej formie zjawiska te są źródłem olbrzymiego cierpienia dotkniętych nimi osób i prawdopodobnie wiążą się z funkcjonalnymi zaburzeniami. Jednak nie wszyscy eksperci z obszaru psychopatologii zgadzają się z tak jednoznacznie negatywnym rozumieniem całej klasy tych zjawisk, zwłaszcza w przypadku, gdy są one problematyczne tylko w określonym kontekście społecznym i dość rozpowszechnione w populacji ogólnej, a także nie przybierają ekstremalnej formy (Wakefield 2007). Na przykład dysleksja nie stanowi problemu w społeczeństwach przedpiśmiennych, a obawa przed byciem ocenionym negatywnie przez grupę może być normalną adaptacją w społeczeństwach, w których wykluczenie społeczne wiąże się z zagrożeniem życia. Należy podkreślić, że konsekwencje niepowodzeń szkolnych mogą być bardzo poważne. Trudno uznać, że wysoki lęk przed byciem ocenianym jest nieuzasadniony i stanowi zaburzenie psychiczne, jeśli w istniejącym systemie społecznym konsekwencją negatywnej oceny osiągnięć szkolnych może być nawet marginalizacja społeczna (Jaggers et al. 2016; Pardej 2016; Rocque, Snellings 2018). Drogi życiowe osób dotkniętych lękiem społecznym, dysleksją czy ADHD wskazują, że osoby, które nie potrafiły w okresie dorastania przystosować się do systemu szkolnego, częściej mają też problemy z adaptacją do dorosłego życia i odnalezieniem się na rynku pracy. Lęk społeczny wiąże się z niższą jakością życia, gorszym funkcjonowaniem wśród ludzi i częstszym porzucaniem szkoły przez uczniów (Stein, Kean 2000). Ponadto osoby z tym zaburzeniem w dorosłym życiu częściej pozostają bez pracy i mają mniejsze dochody, co z oczywistych względów nie pozostaje bez wpływu na ich sytuację ekonomiczną (Patel et al. 2002). Uczniowie cierpiący na ADHD mają niższe osiągnięcia szkolne, częściej mają problemy z uzyskaniem zaliczenia przedmiotu oraz są bardziej narażeni na porzucenie nauki przed uzyskaniem dyplomu (Kent et al. 2011; M.L. Wise, B.L. Wise, Jones 2019). Podobnie dysleksja nie jest tylko problemem „szkolnym”, lecz wywiera wyjątkowo destruktywny wpływ na całość egzystencji osób nią dotkniętych - w tym na ich zdrowie psychiczne, funkcjonowanie społeczne i zawodowe oraz zadowolenie z życia (Livingston, Siegel, Ribary 2018). W tym sensie można stwierdzić, że system szkolnictwa jest zdehumanizowany, gdyż nie uwzględnia on potrzeb i możliwości 
wszystkich uczniów (tych z ADHD, SAD, dysleksją czy innymi specjalnymi potrzebami edukacyjnymi), chociaż obowiązek szkolny dotyczy wszystkich młodych ludzi bez wyjątku. Problem nie polega na tym, że różni uczniowie mają (być może nawet wrodzone) ograniczenia i deficyty, bo jest to naturalna i nieunikniona sytuacja. Problemem jest to, jaki szkoła wywiera na tego typu uczniów wpływ i jak ukierunkowuje ich dalsze, dorosłe już życie. Z dostępnych danych wynika, że przykładowo uczniowie z dysleksją bywają stygmatyzowani społecznie, uznawani za mniej inteligentnych, leniwych lub lekceważących naukę szkolną (Livingston, Siegel, Ribary 2018).

W sytuacji, w której niepowodzenie szkolne wiąże się z marginalizacją społeczną, niższą jakością życia i problemami zdrowia psychicznego i fizycznego, nie dziwi, że część osób podejmuje ekstremalne wysiłki, by uniknąć tego, co nierzadko bywa określane jako tzw. porażka życiowa. Osoby te nadmiernie usiłują być produktywne w nauce i w pracy: kosztem zdrowia, relacji międzyludzkich, szczęścia i - paradoksalnie - skuteczności działań. Całkowita koncentracja na czynnościach o charakterze pracy i bezkompromisowe podporządkowanie im życia skutkuje rozwojem przymusu wykonywania tych czynności. Brak innych źródeł walidacji własnej osoby i ciągły lęk przed porażką $\mathrm{w}$ działaniach $\mathrm{z}$ czasem sprawiają, że człowiek nie potrafi oderwać się od nauki czy pracy i czerpać przyjemności $\mathrm{z}$ innych obszarów życia. Jest to zjawisko wysoce spójne z modelem uzależnienia behawioralnego i jest konceptualizowane jako uzależnienie od pracy (P.A. Atroszko 2019ab; P.A. Atroszko, Demetrovics, Griffiths 2019) i jego wczesna forma w postaci uzależnienia od uczenia się (P.A. Atroszko 2015; 2018; 2019a). Nie dziwi też, że w tej grupie częściej znajdują się osoby z ADHD czy lękiem społecznym (Andreassen et al. 2016; P.A. Atroszko 2015; 2018; 2019a; Atroszko et al. 2017; Marmet et al. 2019), które mogą za wszelką cenę chcieć uniknąć marginalizacji społecznej i osiągnąć sukces w oczach społeczeństwa. Podobnie niedawne badanie wykazało, że pięć na sześć młodych kobiet aktywnych zawodowo, u których zdiagnozowano zaburzenia odżywiania (anoreksja lub bulimia), spełnia kryteria uzależnienia od pracy (P.A. Atroszko, Mytlewska, B. Atroszko 2020). Zaburzenia te są ściśle związane z presją kulturową i społeczną na wygląd, a także z dysfunkcjonalnym perfekcjonizmem. Niosą one ze sobą także wyjątkowo wysokie ryzyko samobójstw i samookaleczania. Uzależnienie od pracy i uczenia się jest też związane z narcyzmem (P.A. Atroszko, Sawicki, Kamble 2019), który jest rosnącym problemem społecznym ściśle łączącym się z potrzebą wyższego statusu społecznego i podziwu.

O ile osoby, które wykazują trudności z uczeniem się czy niską inteligencję, mogłyby zostać cynicznie „spisane na straty” w społeczeństwie mającym obsesję sukcesu socjoekonomicznego, o tyle sprawa się nieco komplikuje w przypadku osób uzależnionych od uczenia się i pracy. Są one bowiem wysoce sumienne, pracowite, nierzadko zdolne lub bardzo zdolne oraz wyznające wartości prospołeczne (P.A. Atroszko 2015, 2018, 2019a; P.A. Atroszko, Demetrovics, Griffiths 2019). Innymi słowy, są to osoby, na których każdemu ustawodawcy, pracodawcy, 
dyrektorowi szkoły i rektorowi uczelni wyższej powinno bardzo zależeć. Są to osoby, które mogą zwiększyć szanse sukcesu socjoekonomicznego kraju, przedsiębiorstwa, szkoły i uczelni. Co więcej, są to osoby, które mogłyby wpłynąć pozytywnie na ogólną jakość życia społecznego poprzez swój wkład w poprawę funkcjonowania instytucji społecznych. A jednak pozwalamy, żeby ten olbrzymi kapitał ludzki się marnował. Dlaczego? Być może dlatego, że nie dostrzegamy, jak pewne procesy społeczno-ekonomiczno-kulturowe działają na szkodę populacji całego kraju, co widać $\mathrm{w}$ statystykach samobójstw i potrzeb opieki psychiatrycznej przekraczających możliwości istniejącego systemu opieki medycznej.

\section{Znaczenie uzależnienia od pracy i uczenia się}

Badania wskazują, że zmiany ekonomiczno-społeczne zachodzące w środowisku młodzieży, takie jak obniżenie standardu życia, świadomość nierówności wynikającej z odczuwanej różnicy w standardzie życia, bezrobocie rodziców czy niemożność realizacji marzeń z powodu braku środków materialnych mogą być czynnikami wzmacniającymi tendencje samobójcze (Makara-Studzińska 2013). Jednak presja na sukces socjoekonomiczny nie służy nie tylko najbiedniejszym i „niezaradnym”, ale również osobom dobrze usytuowanym, zwłaszcza dzieciom ze środowisk o wysokim statusie socjoekonomicznym. Kulturową ekspresją tego zjawiska jest fenomen utworu Patointeligencja, który pod koniec 2019 roku uzyskał niebywałą popularność na platformie YouTube. Dotyczy on problemów behawioralnych i psychologicznych zamożnej młodzieży. Wydaje się wołaniem o skierowanie uwagi na zjawisko, które od dawna jest dobrze udokumentowane w literaturze naukowej. (Hanson, Chen 2007; Luthar, Becker 2002). Na poziomie statystycznym natomiast wyrazem polskiej patologii jest rozpowszechnienie uzależnienia od pracy, które jest dwa do trzech razy wyższe niż w takich krajach jak Norwegia, Dania czy Szwajcaria (P.A. Atroszko, B. Atroszko 2020). Co więcej, polskie badania sugerują, że dzieci osób uzależnionych od pracy funkcjonują psychicznie gorzej niż dzieci osób uzależnionych od alkoholu czy z rozbitych rodzin (Polok et al. 2018). Analizy te są spójne z ustaleniami wybitnego badacza tej tematyki Bryana E. Robinsona (2014) $\mathrm{z}$ lat dziewięćdziesiątych XX wieku czy z wynikami uzyskanymi przez innych współczesnych naukowców (Shimazu et al. 2020). Najważniejszymi czynnikami wpływającymi na podejmowane próby samobójcze młodzieży są emocjonalne odrzucenie przez osoby bliskie i ważne, świadomość negatywnej oceny przez innych oraz samotność (Makara-Studzińska 2013). W tym kontekście kluczowe są relacje $\mathrm{w}$ rodzinie, $\mathrm{w}$ tym problemy $\mathrm{w}$ relacji $\mathrm{z}$ rodzicami, takie jak uczucie emocjonalnego odtrącenia, konflikty, zerwanie więzi w wyniku śmierci jednego lub obojga rodziców, alkoholizm matki lub ojca oraz kłótnie między nimi. Są one wymieniane jako jedne z najważniejszych przyczyn podejmowania prób samobójczych przez nastolatków oraz doświadczanych przez nich problemów psychicznych (Namysłowska 2013). 
Przepracowanie, depresja i lęk, nadużywanie alkoholu, śmierć wskutek powikłań zdrowotnych, a także wypalenie zawodowe związane z uzależnieniem od pracy (Griffiths, Demetrovics, P.A. Atroszko 2018), warunkowe zainteresowanie dziećmi wśród pracoholików (m.in. koncentracja na osiągnięciach dzieci, wysokie wymagania; Robinson 2014) czy po prostu ograniczony kontakt wskutek długich godzin spędzanych w pracy - to tylko niektóre z czynników, które mogą wpływać na złą relację uzależnionego od pracy rodzica z dzieckiem. Dzieci pracoholików mają także wyższe ryzyko uzależnienia od pracy, co niejako gwarantuje pokoleniowy przekaz patologii (Kravina et al. 2014).

Brak wsparcia psychologicznego i psychiatrycznego dla osób ze środowisk o niskim statusie socjoekonomicznym teoretycznie można by wyjaśnić niską troską o najbiedniejszych i najbardziej potrzebujących na poziomie społeczeństwa i państwa, a w konsekwencji niewielkimi nakładami finansowymi na pomoc tym grupom. W ten sposób nie można jednak wyjaśnić rosnących problemów zdrowia psychicznego wśród zamożnych grup społecznych. W tej sytuacji pojawia się pytanie, dlaczego osoby bogate i ich dzieci doświadczają poważnych konsekwencji zaburzeń zdrowia psychicznego? Dlaczego w tej grupie społecznej rozpowszechnienie wielu problemów psychicznych i behawioralnych nie różni się szczególnie wyraźnie w stosunku do osób ze środowisk najuboższych? Jednym z teoretycznych modeli, które mogą być użyteczne w wyjaśnieniu (do pewnego stopnia) tych zjawisk, jest model uzależnienia. Cechą definicyjną uzależnienia jest utrata kontroli nad zachowaniem. Znaczenie konceptualizacji tych problemów w kontekście uzależnienia od pracy i uczenia się pozwala zrozumieć, dlaczego od dekad nie potrafimy nad nimi zapanować. Wyjaśnia to także takie zjawiska jak wysokie rozpowszechnienie uzależnienia od pracy wśród kadry kierowniczej, która nie należy do najbiedniejszych grup społecznych (P.A. Atroszko, B. Atroszko 2020). Nacisk na produktywność, sukces materialny oraz wysoki status społeczny może u podatnych na nie osób prowadzić do utraty kontroli nad zaangażowaniem w pracę czy nauką - podobnie jak społeczny i medialny nacisk na standardy urody jest jednym z najważniejszych czynników ryzyka zaburzeń odżywiania wśród kobiet (P.A. Atroszko, Mytlewska, B. Atroszko 2020).

Kolejnym kluczowym aspektem uzależnień są mechanizmy wyparcia i zaprzeczania. Ponad $90 \%$ osób uzależnionych nigdy nie rozpoznaje problemu i nie szuka pomocy (Goldstein et al. 2009). To z kolei pozwala wyjaśnić, dlaczego pomimo regularnych sygnałów w postaci raportów o stanie opieki psychiatrycznej w Polsce (Moskalewicz, Kiejna, Wojtyniak 2012; Komisja Ekspertów przy Rzeczniku Praw Obywatelskich 2014; Sekcja Ochrony Zdrowia Narodowej Rady Rozwoju 2016; Najwyższa Izba Kontroli 2020) absolutnie nic się nie zmienia i z roku na rok jest coraz gorzej. Uwarunkowania kryzysu psychiatrii w Polsce z pewnością są złożone. Jednak w obecnej sytuacji najbardziej zadziwiająca jest jedna kwestia: nikt nie zadaje sobie pytania o to, dlaczego systematycznie rośnie psychopatologia wśród najmłodszych pokoleń w Polsce. Jakie mechanizmy sprawiają, że mimo polepszających 
się warunków materialnych społeczeństwa jakość życia psychicznego kolejnych pokoleń jest coraz gorsza? Dlaczego psychopatologia jest dość powszechna wśród zamożnych środowisk? W tej sytuacji można by mówić o wyparciu na poziomie społeczeństwa. Problemem jest stygmatyzacja zaburzeń psychicznych i nierzadko postrzeganie ich jako problem właśnie osób „niezaradnych życiowo” czy „słabych”. Zagadnienie jest konceptualizowane w kategoriach: jak zwiększyć liczbę łóżek na dziecięcych i młodzieżowych oddziałach psychiatrycznych i jak zachęcić więcej lekarzy do specjalizacji psychiatrycznej. Oczywiście należy to zrobić, ale jest to przejawem myślenia ograniczonego do pytania ,jak zrobić czegoś więcej?” - jak być bardziej produktywnym w tym obszarze, pomijając szerszy kontekst zjawiska. Wydaje się natomiast, że kluczowe pytanie, które powinniśmy sobie zadawać w tej sytuacji, to: jak zapobiegać i zmniejszać psychopatologię najmłodszych? A to wymaga zrozumienia, skąd ona się bierze. System opieki psychiatrycznej jest niewydolny od lat i wydaje się praktycznie niemożliwe, aby jego rozwiązaniem było niekończące się zwiększanie liczby łóżek szpitalnych i specjalistów - zwłaszcza że nawet to nie następuje w żadnym realnie istotnym stopniu. Obecnie w większości województw przypada mniej niż dwóch lekarzy psychiatrów na tysiąc pacjentów małoletnich (Najwyższa Izba Kontroli 2020). Konieczne są wyraźne zintegrowane wysiłki mające na celu zrozumienie, skąd się obecna sytuacja bierze - mające swoje źródło w polityce badawczej państwa (nacisk na badania zmierzające do zrozumienia i przeciwdziałania tym procesom), poprzez reformę systemu edukacji oraz działania profilaktyczne na poziomie populacyjnym, w tym kształcenie specjalistów w tych obszarach. Oczywiście bezwzględnie konieczne jest zwiększenie nakładów na opiekę psychiatryczną.

Przy tej okazji warto zwrócić uwagę na kolejny aspekt problemu. Lekarze, pielęgniarki oraz inni pracownicy służby zdrowia mają wysokie ryzyko uzależnienia od pracy i bardzo wysokie wskaźniki wypalenia zawodowego (West et al. 2016; Imo 2017; Walkiewicz, Sowińska, Tartas 2014). Stan ten jest udokumentowanym czynnikiem wpływającym na gorszą jakość wykonywanej pracy (Salvagioni et al. 2017), a w przypadku lekarzy na liczbę popełnianych błędów medycznych (Tawfik et al. 2018). Polscy lekarze, podobnie jak japońscy, oficjalnie rozpoznali przeciążenie pracą jako podstawową przyczynę śmierci w przypadkach, gdy lekarze umierają po bardzo długich dyżurach (trwających dłużej niż 24 godziny; Ogólnopolski Związek Zawodowy Lekarzy 2017; Hiyama, Yoshihara 2008; Uehata 2005). O ile niewydolność polskiego systemu opieki medycznej ma zapewne liczne uwarunkowania, o tyle wydaje się wysoce prawdopodobne, że duże rozpowszechnienie chorób wynikających z przeciążenia pracą i stresu zawodowego na poziomie populacyjnym (Atroszko, Demetrovics, Griffiths 2020) jest jednym z jego ważnych źródeł. To zjawisko wskazuje na potencjalnie istotny aspekt dynamiki problemu uzależnienia od pracy i jego konsekwencji. Mianowicie - duże rozpowszechnienie uzależnienia od pracy w populacji może powodować znacznie częstsze występowanie chorób i zaburzeń z nim związanych, w tym wśród dzieci i młodzieży (bezpośrednio jako 
efekt problemów rodziców i pośrednio poprzez uzależnienie od uczenia się samych uczniów i studentów), a to z kolei może powodować przeciążenie innych systemów (opieki zdrowotnej, pomocy społecznej, edukacji itp.). To w dalszej kolejności może prowadzić do pogłębienia powyższych problemów, błędnego koła przepracowania i jego konsekwencji. Wydaje się wysoce prawdopodobne, że istotna część obecnego kryzysu psychiatrii dziecięcej może być efektem tego mechanizmu.

\section{Uzależnienie od pracy - aktualny stan wiedzy}

Kompulsywne przepracowywanie się od połowy XX wieku jest oficjalnie uznawane za problem psychiatryczny. Jest ono jednym z objawów obsesyjno-kompulsywnego zaburzenia osobowości (OCPD) w „Diagnostycznym i statystycznym podręczniku zaburzeń psychicznych” (DSM; APA 2013), które funkcjonuje pod nazwą anankastycznego zaburzenia osobowości (APD) w Międzynarodowej Klasyfikacji Chorób (ICD; obecnie, zgodnie z ICD-11, anankastia w zaburzeniach osobowości). Jeden z objawów tego zaburzenia osobowości dotyczy nadmiernego poświęcenia się pracy i produktywności kosztem rodziny i relacji społecznych, a także odpoczynku i czasu wolnego. Klasyfikacje chorób i zaburzeń intensywnie ewoluują i jeden problem jest opisywany pod różnymi nazwami i klasyfikowany w różny sposób w miarę, jak coraz lepiej go rozumiemy. Pierwsze wydanie DSM-I (APA 1952) opisywało problem osobowości kompulsywnej z takimi cechami jak „nadmierna zdolność do pracy” i „brak normalnej zdolności do relaksacji” (APA 1952: 37). Symptom kompulsywnej potrzeby produktywności znajdował się wśród objawów OCPD od czasu DSM-III (APA 1980), a wśród objawów APD od ICD-8. W literaturze medycznej często nazywano to „pracoholizmem”. Wraz z dynamicznym rozwojem rozumienia uzależnień behawioralnych wskazuje się jednak, że wzorzec utraty kontroli nad zaangażowaniem w pracę prawdopodobnie lepiej wpisuje się w ramy behawioralnego uzależnienia i można go konceptualizować jako uzależnienie od pracy (P.A. Atroszko 2019ab). W takim przypadku OCPD/anankastia jest prawdopodobnie ważnym czynnikiem ryzyka. Zaburzenie to objawia się perfekcjonizmem (np. troską o reguły społeczne, obowiązki i normy dobra i zła, skrupulatną dbałością o szczegóły, sztywnymi, systematycznymi, codziennymi czynnościami, nadmiernym planowaniem i tworzeniem grafików, naciskiem na organizację, porządek i schludność) oraz ograniczeniem emocjonalnym i behawioralnym (np. uporem i brakiem elastyczności, unikaniem ryzyka, wytrwałością). Uzależnienie od pracy objawia się jednak w sposób, który nie jest charakterystyczny dla zaburzenia osobowości (np. odstawienne i utrata kontroli).

W ostatnim dwudziestoleciu, a w szczególności w ciągu ostatnich dziesięciu lat, dokonano znaczących postępów w badaniach nad uzależnieniem od pracy i jego konceptualizacji (P.A. Atroszko, Griffiths 2017). Zaowocowały one debatą na łamach czasopisma „Journal of Behavioral Addictions”, w której udzieliło się 
wielu czołowych badaczy tego zjawiska na świecie (Andreassen, Schaufeli, Pallesen 2018; Kun 2018; Lior, Abira, Aviv 2018; Loscalzo, Giannini 2018a; Malinowska 2018; Quinones 2018; Sussman 2018; Tóth-Király, Bőthe, Orosz 2018). Wśród autorów znajdowali się badacze, którzy w ostatnich latach publikowali artykuły przeglądowe na ten temat (Andreassen 2014; Andreassen, Pallesen 2016; Griffiths, Demetrovics, P.A. Atroszko 2018; Quinones, Griffiths 2015; Sussman 2012). W wyniku tej dyskusji wyłoniono kilka ogólnych wniosków. Po pierwsze, uzależnienie od pracy jest realnym problemem o charakterze zaburzenia psychicznego, mającym uzasadnienie w zgromadzonych danych. Po drugie, obecnie jest wystarczająco dużo danych, aby potwierdzić jego negatywne konsekwencje, w szczególności upośledzenie funkcjonowania o znaczeniu klinicznym. Po trzecie, istnieją dowody na to, że u niektórych osób uzależnienie od pracy utrzymuje się przez dłuższy czas, a nie jest tylko przejściowym wzorcem zachowania. Po czwarte, przyczyny jego rozwoju nie ograniczają się do czynników osobowościowych i potrzebne są dalsze badania nad czynnikami ryzyka na poziomie mezo (np. związane z organizacją pracy w przedsiębiorstwach) i makro (np. kulturowe czy socjoekonomiczne; zob. P.A. Atroszko, Demetrovics, Griffiths 2019, 2020).

Ponadto zaproponowano ogólną definicję uzależnienia od pracy (P.A. Atroszko, Demetrovics, Griffiths 2019). Opiera się ona na modelu uzależnienia behawioralnego, jest spójna z dotychczasowymi definicjami i ma na celu ułatwić systematyczne i zintegrowane badania nad kryteriami diagnostycznymi uzależnienia od pracy i ich walidacją. Takie powszechnie przyjęte kryteria umożliwiłyby dalszą spójną analizę tego zjawiska, w tym dokładniejsze oszacowanie jego rozpowszechnienia. Nowa ogólna definicja, dookreślająca także niektóre objawy, jest następująca:

Uzależnienie od pracy charakteryzuje się przymusem pracy i zaabsorbowaniem czynnościami o charakterze pracy, które powodują poważny stres i mają istotny, szkodliwy wpływ na funkcjonowanie osoby i/lub jej relacje z bliskimi (przyjaciółmi, rodziną). Zachowanie to charakteryzuje się utratą kontroli nad wykonywaną pracą i utrzymuje się przez dłuższy czas. To problematyczne zachowanie związane z pracą może mieć różne nasilenie, od łagodnego do ciężkiego (P.A. Atroszko, Demetrovics, Griffiths 2019: 9)1.

Badania bazujące na najlepszej dostępnej metodologii pomiaru uzależnienia od pracy wskazują, że jego rozpowszechnienie wynosi od 6,6\% do 20,6\% w zależności od kraju (Andreassen et al. 2014; Lichtenstein et al. 2019; Marmet et al. 2019; Orosz et al. 2016), przy czym w Polsce wynosi ono 17,4\% (P.A. Atroszko et al. 2017). Jest ono bardziej rozpowszechnione niż większość uzależnień, a OCPD/anankastia jest najczęściej występującym zaburzeniem osobowości w populacji ogólnej (3\%-8\%) i wśród grup klinicznych. Oba zaburzenia wykazują silny związek ze stresem i wypaleniem zawodowym. Przeciążenie pracą i stres zawodowy uznano za czynniki ryzyka chorób i zaburzeń, które powszechnie dotykają ludzkość (np. choroby układu sercowo-naczyniowego, depresja, cukrzyca; Bannai, Tamakoshi 2014;

\footnotetext{
${ }^{1} \mathrm{O}$ ile nie zaznaczono inaczej, tłumaczenia cytatów wykonali autorzy artykułu.
} 
Virtanen et al. 2012). W związku z tym można przypuszczać, że kompulsywne przepracowywanie się może być pośrednio odpowiedzialne za znaczną część wypalenia zawodowego i globalne obciążenie chorobami. Zaproponowano ogólny model zależności między tymi zjawiskami i ich potencjalnymi determinantami na poziomie mikro, mezo i makro (P.A. Atroszko, Demetrovics, Griffiths 2020). WHO definiuje wypalenie zawodowe jako zjawisko

wynikające z chronicznego stresu w miejscu pracy, którego nie udało się skutecznie opanować. Charakteryzuje się ono trzema wymiarami:

- uczuciem zmniejszenia poziomu energii lub wyczerpania;

- zwiększonym dystansem psychicznym do własnej pracy lub poczuciem negatywizmu lub cynizmu związanym $\mathrm{z}$ wykonywaną pracą; oraz

- zmniejszeniem efektywności zawodowej (WHO 2019).

Obecnie wypalenie zawodowe przybiera wymiary „epidemii”, szczególnie w zawodach związanych z opieką zdrowotną (Imo 2017; Panagioti et al. 2017), a także $\mathrm{w}$ ramach systemu szkolnictwa wyższego. Jego wysokie rozpowszechnienie jest obserwowane między innymi wśród doktorantów (Levecque et al. 2017; Nature 2019). Jego symptomy można zauważyć już u uczniów szkół średnich (Walburg 2014).

Światowy plan działania WHO na rzecz zdrowia pracowników (2008-2017) i zdrowia psychicznego (2013-2030) określają odpowiednie zasady, cele i strategie wdrażania mające na celu wspieranie zdrowia psychicznego $\mathrm{w}$ miejscu pracy (WHO 2019). Zwrócono jednak uwagę, że plan ten w żaden bezpośredni sposób nie odnosi się do problemu uzależnienia od pracy, a w szczególności ignoruje takie sytuacje jak samozatrudnienie (w Polsce jest około 3 milionów jednoosobowych działalności gospodarczych, co stanowi blisko $20 \%$ rynku pracy, podobnie jak w wielu innych krajach). Konkretny program wdrażania planów WHO mógłby skorzystać na uwzględnieniu specyfiki uzależnienia od pracy.

Jednym z najnowszych osiągnięć teoretycznych jest postulat, że uzależnienie od pracy może występować już w latach szkolnych i na studiach oraz dotyczyć kompulsywnej pracy szkolnej/studiowania (P.A. Atroszko 2013, 2015; B. Atroszko, P.A. Atroszko 2013; P.A. Atroszko et al. 2015; Griffiths, Demetrovics, P.A. Atroszko 2018). Jest to zgodne z ustaleniami, że na ogół uzależnienia zaczynają się rozwijać w młodości. Wyróżnienie uzależnienia od uczenia się jako swoistego obszaru badawczego ma duże znaczenie z trzech głównych powodów. Po pierwsze, uwzględnia specyfikę kompulsywnej potrzeby wykonywania czynności o charakterze pracy w odniesieniu do czynności związanych z uczeniem się (i funkcjonowaniem systemów edukacji), które mogą wykazywać pewne różnice w stosunku do populacji osób pracujących zawodowo. Na przykład badania pokazują wyraźnie wyższe rozpowszechnienie uzależnienia od uczenia się wśród uczennic i studentek (np. ponad trzy razy częstsze wśród licealistek) w porównaniu do uczniów i studentów (P.A. Atroszko 2015; Wróbel 2020). Różnice takie nie są obserwowane w populacji osób pracujących zawodowo. Po drugie, trafność pomiaru uzależnienia od uczenia się za pomocą 
narzędzi badania uzależnienia od pracy jest ograniczona. Konieczne zatem było stworzenie trafnych i rzetelnych narzędzi pomiarowych odzwierciedlających specyfikę procesu uczenia się (P.A. Atroszko 2015; P.A. Atroszko et al. 2015; Wróbel 2020). Po trzecie, skuteczne przeciwdziałanie temu zjawisku wymaga oddziaływań profilaktycznych na poziomie populacyjnym uwzględniających potrzeby młodych ludzi i specyfikę ich funkcjonowania w systemie edukacji. Również oddziaływania terapeutyczne powinny brać pod uwagę czynniki związane z okresem rozwojowym w życiu młodych osób doświadczających negatywnych konsekwencji kompulsywnego przepracowywania się.

W tym kontekście szczególnym problemem, który nie został wyraźnie zidentyfikowany przez WHO, jest rola systemów edukacyjnych. Mogą one być źródłem czynników ryzyka kompulsywnego przepracowania na poziomie makro (np. polityka standaryzowanych testów i nacisk na wąsko rozumiany sukces edukacyjny, ogólna kultura rywalizacji) i mezo (np. klimat w klasie, style nauczania, zarządzanie szkołą) przyczyniające się do uzależnienia od uczenia się (zob. P.A. Atroszko, Demetrovics, Griffiths 2020). Wczesna profilaktyka jest prawdopodobnie jedną z najlepszych praktyk ograniczających szkody wynikające z problematycznych zachowań.

\section{Uzależnienie od uczenia się: aktualny stan wiedzy}

Uzależnienie od uczenia się zostało formalnie zdefiniowane dopiero niedawno i w literaturze klinicznej trwa proces jego ścisłej konceptualizacji (P.A. Atroszko 2013, 2015, 2018, 2019a; B. Atroszko, P.A. Atroszko 2013; Wróbel 2020). Jednak kompulsywne, nadmierne uczenie się, rozumiane implicite jako forma uzależnienia od pracy, było badane wśród studentów od blisko trzydziestu lat - głównie w ramach analizy walidacyjnych narzędzi psychometrycznych służących do pomiaru uzależnienia od pracy (P.A. Atroszko 2010; Chamberlin, Zhang 2009; Robinson 1999; Spence, Robbins 1992; Sussman et al. 2014; Sussman et al. 2015; Tsai et al. 2016; Villella et al. 2011). Uzależnienie od uczenia jest konceptualizowane jako wczesna forma uzależnienia od pracy (P.A. Atroszko 2015, 2018, 2019a; P.A. Atroszko et al. 2015; Griffiths, Demetrovics, P.A. Atroszko 2018). Można je zatem zdefiniować w analogiczny sposób:

Uzależnienie od uczenia się charakteryzuje się przymusem uczenia się i zaabsorbowaniem czynnościami związanymi z nim, które powodują poważny stres i mają istotny, szkodliwy wpływ na funkcjonowanie osoby i/lub jej relacje z bliskimi (przyjaciółmi, rodziną). Zachowanie to charakteryzuje się utratą kontroli nad uczeniem się i utrzymuje się przez dłuższy czas. To problematyczne zachowanie związane z uczeniem się może mieć różne nasilenie, od łagodnego do ciężkiego (P.A. Atroszko, Sawicki, Kamble 2019: 2).

W badaniach podłużnych wykazano związek uzależnienia od uczenia się z uzależnieniem od pracy po ukończeniu studiów i podjęciu pracy zawodowej (P.A. Atroszko 
et al. 2016a) oraz podobną stabilność czasową obu zjawisk (P.A. Atroszko et al. 2016b). Oba wykazują siedem głównych objawów uzależnienia (dominacja, zmiana nastroju, objawy abstynencyjne, tolerancja, nawrót, konflikty wewnętrzne i zewnętrzne, a także problemy zdrowotne oraz inne problemy z funkcjonowaniem) i wiążą się z większym zaangażowaniem w daną aktywność (uczenie się/pracę) oraz dłuższym czasem poświęconym jej, kluczowymi cechami osobowości (wyższą neurotycznością i sumiennością, a także wzorcem osobowości typu A), niższym poziomem efektywności działania, pogorszeniem ogólnego stanu zdrowia, obniżoną jakością życia, gorszym snem oraz wyższym odczuwalnym stresem (P.A. Atroszko 2015; P.A. Atroszko et al. 2015; P.A. Atroszko, B. Atroszko 2019; P.A. Atroszko et al. 2019; Lawendowski et al. 2019).

Badania dotyczące rozpowszechnienia uzależnienia od uczenia się bazujące na analogicznej metodologii badań uzależnienia od pracy wykazały, że wynosiło ono $6,4 \%$ wśród polskich studentów w próbie oportunistycznej na zajęciach na uczelni oraz 14,2\% w próbach online w Polsce i 9,7\% w Norwegii (P.A. Atroszko 2015). W populacji studentów polskich akademii muzycznych, szczególnie wrażliwych ze względu na wysoki poziom perfekcjonizmu i często ograniczone wsparcie społeczne, rozpowszechnienie wyniosło 16\% (Lawendowski et al. 2019). Wśród uczniów polskich szkół średnich - 15,4\% (Wróbel 2020), a w szkołach średnich w Indiach - 7\% (Bisht, Godiyal 2018).

Istnieją różne ramy pozwalające odróżnić zdrowe i niezdrowe zaangażowanie w określone zachowania (np. Vallerand 2015). Należy jednak podkreślić, że uzależnienie od uczenia się dobrze wpisuje się w diagnostyczne kryteria uzależnienia behawioralnego. Fenomenologicznie prezentuje się jako zachowanie kompulsywne, wykazuje związek z pogorszonym funkcjonowaniem i jest czasowo stabilne. Są to jedne z kluczowych kryteriów rozróżniania zaburzeń psychicznych od zdrowych form zachowania lub przejściowych trudności (zob. P.A. Atroszko 2019ab; P.A. Atroszko, Griffiths 2017; Griffiths, Demetrovics, P.A. Atroszko 2018; P.A. Atroszko, Demetrovics, Griffiths 2019). Zaproponowano, że nadmierne uczenie się może być specyficzną formą zaburzenia obsesyjno-kompulsywnego (Loscalzo, Giannini 2018ab). Jednak po dokładnym przeanalizowaniu tych sugestii wykazano, że dane wydają się bardziej zgodne z modelem, w którym obsesyjno-kompulsywność leży u podstaw niektórych rodzajów uzależnienia od pracy/uczenia się (ale nie wszystkich). Wstępnie zaproponowano, że niektóre formy OCPD mogą zostać przeklasyfikowane jako uzależnienie od pracy/uczenia się (P.A. Atroszko 2018, 2019ab; P.A. Atroszko, Demetrovics, Griffiths 2019). Aby jednak zrozumieć naturę, różne formy i podstawowe czynniki ryzyka tego problematycznego zachowania, wciąż potrzeba więcej badań. 


\section{Uzależnienie od uczenia się jako nieefektywna strategia radzenia sobie ze stresem}

Uzależnienie od uczenia się jest konceptualizowane jako nieskuteczna strategia radzenia sobie ze stresem mająca służyć - w założeniu - zaspokajaniu podstawowych potrzeb uczniów i/lub studentów (P.A. Atroszko 2015). Zaproponowany model teoretyczny został zwalidowany w obszernych i systematycznych badaniach międzykulturowych (P.A. Atroszko 2015, 2018, 2019a; Lawendowski et al. 2019). Zakłada on unikalną interakcję między dyspozycjami temperamentalnymi i osobowościowymi (np. dużą podatnością na przeżywanie negatywnych emocji i dużą sumiennością) oraz wczesnymi doświadczeniami w środowisku rodzinnym i społecznym, które mogą powodować niską samoocenę, poczucie nieadekwatności i niezaspokojenia podstawowych potrzeb psychologicznych (tj. autonomia, kompetencje i poczucia przynależności; Deci, Ryan 2000). Ponadto te czynniki ryzyka mogą najpierw przyczyniać się do rozwoju innych zaburzeń, takich jak SAD, ADHD lub OCPD (P.A. Atroszko 2018, 2019ab). Uzależnienie od uczenia się może być zatem zachowaniem kompensacyjnym $\mathrm{w}$ radzeniu sobie $\mathrm{z}$ wyżej wymienionymi zaburzeniami, a także innymi problemami behawioralnymi i emocjonalnymi. Model ten jest wciąż rozwijany i uszczegóławiany (zob. P.A. Atroszko, Lawendowski 2020; Wróbel 2020). Osoby wrażliwe, poprzez społeczne uczenie się oraz wpływ norm i wartości kulturowych, mogą rozwinąć przekonanie, że ciężka praca prowadzi do sukcesu, co z kolei zapewni im sympatię i szacunek innych, zaspokajając w ten sposób potrzebę związku z innymi ludźmi. Również potrzeby autonomii i kompetencji mogą zostać zaspokojone w ramach aktywności związanych z procesem uczenia się. Model zakłada również, że osoby skłonne do uzależnienia od uczenia się dorastają w środowiskach, które nie rozwijają skutecznych sposobów radzenia sobie ze stresem i problemami osobistymi na przykład poprzez wsparcie społeczne, zwłaszcza kochający i akceptujący klimat rodzinny, czy przewartościowanie trudnej sytuacji. Rodzice takich osób często są uzależnieni od pracy lub mają inne nałogi, a zarazem często mają perfekcjonistyczne oczekiwania wobec swoich dzieci lub są nadopiekuńczy względem nich. Dynamika rodziny w uzależnieniu od pracy była systematycznie badana przez Robinsona (2014) od lat dziewięćdziesiątych i wykazała między innymi, że uzależnienie od pracy może być zachowaniem kompensacyjnym w przypadku chaotycznego środowiska domowego.

Wysoka sumienność, która jest wyraźną cechą osób uzależnionych od nauki, w początkowych stadiach może umożliwić im podjęcie zachowań zmierzających do osiągnięcia wyższych wyników w nauce. Dobre oceny, pochwały od nauczycieli i rodziców, stypendia i nagrody, podziw rówieśników lub po prostu zadowolenie z opanowania materiału lub umiejętności - to jedne z wielu pozytywnych wzmocnień, które początkowo powodują, że nauka wiąże się z przyjemnością i satysfakcją. Co więcej, nauka jest bardzo angażująca poznawczo i może być sposobem 
na ucieczkę od negatywnych emocji wywołanych przez nierozwiązane problemy osobiste. Znajduje to spójne uzasadnienie w badaniach pokazujących, że wśród komponentów zaangażowania najsilniej z uzależnieniem od uczenia się związana jest absorpcja (odnosi się to do pełnej koncentracji i szczęścia podczas pochłonięcia przez naukę, kiedy czas mija szybko i ma się trudności z oderwaniem się od działania) z uzależnieniem od nauki i od pracy (zob. P.A. Atroszko, B. Atroszko 2019; Loscalzo, Giannini 2020). Z czasem jednak nierozwiązane problemy kumulują się i przyczyniają się do podnoszenia poziomu doświadczanego stresu. Początkowe pozytywne emocje zaczynają zanikać i są zastępowane przez negatywne uczucia niepokoju i irytacji, gdy osoba próbuje powstrzymać nadmierne uczenie się (P.A. Atroszko 2015).

Z czasem nauka staje się jedynym źródłem zaspokajania potrzeb w zakresie autonomii, kompetencji i przynależności. Fiksacja na tej jednej dziedzinie życia i silna potrzeba zdobywania w niej osiągnięć prowadzi do dodatkowego stresu, gdyż ich brak oznacza całkowitą porażkę i nadszarpniętą samoocenę. Uczenie się przestaje zatem być przyjemnym zajęciem i staje się niekontrolowanym przymusem, ponieważ osoba musi się uczyć, aby potwierdzić swoją wartość, gdyż nie opracowała alternatywnych sposobów zaspokojenia tych trzech potrzeb. Kompulsja prowadzi więc do dalszego zaniedbywania innych sfer życia, zwłaszcza relacji z bliskimi, a także zaniedbywania problemów zdrowotnych powstałych w wyniku nadmiernego wysiłku włożonego w naukę. Co więcej, sama nauka nie przynosi korzyści proporcjonalnych do włożonego wysiłku. Strach przed utratą sympatii i szacunku w wyniku okazywania niekompetencji przez popełnianie błędów powoduje, że osoba jest nadmiernie skupiona i poświęca zbyt wiele czasu na nieistotne szczegóły, tworząc w ten sposób dysproporcję między wysiłkiem a niezadowalającymi wynikami, które powodują dodatkowy stres.

W kontekście tego modelu i tematu obecnego artykułu bardzo ważne wydają się wyniki badań wskazujące, że uzależnienie od uczenia się jest związane z relatywnie niższym statusem socjoekonomicznym (P.A. Atroszko 2013; B. Atroszko, P.A. Atroszko 2013). Jest to zgodne z oczekiwaniem, że osoby sumienne i pracowite w obliczu względnie gorszej, w stosunku do innych osób, sytuacji socjoekonomicznej podejmą odpowiednio większe wysiłki, by zmienić swój status społeczny i materialny. Wydaje się to naturalnym i zasadniczo pozytywnym zjawiskiem, natomiast zagrożenie kryje się w całkowitym podporządkowaniu życia temu jednemu celowi, co potencjalnie w dłuższej perspektywie czasowej może być źródłem nowych problemów. 
Relacja między uzależnieniem od uczenia się

a zaangażowaniem w uczenie się

Jednym z kluczowych pojęć potrzebnych do zrozumienia procesu uczenia się i zachowań uczniów jest „,zaangażowanie w uczenie się”. Definiuje się je jako wielowymiarowy konstrukt. Ma on wiele różnych konceptualizacji. Niemniej komponenty wspólne dla większości teoretycznych ujęć opisują pozytywne emocje związane z uczeniem się, identyfikację z zajęciem, gotowość do zainwestowania w nie dużej ilości czasu i wysiłku oraz wysoki poziom koncentracji podczas uczenia się (Appleton, Christenson, Furlong 2008; Schaufeli, Salanova et al. 2002).

Jedna $\mathrm{z}$ konceptualizacji bazuje na modelu zaangażowania $\mathrm{w}$ pracę i obejmuje trzy wymiary: 1) wigor (chęć zainwestowania dużej ilości czasu i wysiłku w uczenie się oraz prężność psychiczna podczas tej czynności), 2) dedykacja (poczucie sensu, podekscytowanie i duma odczuwane w odniesieniu do uczenia się) oraz 3) absorpcja (silne skupienie i bycie całkowicie pochłoniętym w trakcie uczenia się, tak że czas płynie szybko i trudno jest się oderwać od tej czynności; Schaufeli, Martinez et al. 2002; Schaufeli, Salanova et al. 2002). Badania dotyczące tej konceptualizacji w odniesieniu do pracy wykazały, że uzależnienie od pracy i zaangażowanie w nią wyraźnie różnią się pod względem determinantów i konsekwencji. Mimo to mają pewne cechy wspólne - obejmujące znaczny czas i wysiłek poświęcany danej czynności (Clark et al 2016; Di Stefano, Gaudiino 2019). Obecnie panuje ogólny konsensus, że uzależnienie od pracy jest innym zjawiskiem niż zaangażowanie w nią. Wciąż jednak potrzeba więcej badań, aby dokładnie określić, kiedy zaangażowanie staje się nadmierne i szkodliwe, przeradzając się w uzależnienie (P.A. Atroszko, Demetrovics, Griffiths 2019; Di Stefano, Gaudiino 2019).

Konceptualizacja związku między zaangażowaniem w uczenie się a uzależnieniem od niego opiera się na postulatach teoretycznych i ustaleniach empirycznych dotyczących związku między uzależnieniem od pracy a zaangażowaniem w nią (P.A. Atroszko 2015, 2018). Zakłada ono wspólne elementy w postaci znacznego wkładu czasu i wysiłku w naukę, a różne mechanizmy regulacyjne (zaangażowanie związane jest ze zrównoważonym stylem życia i pozytywnymi emocjami, a uzależnienie determinowane jest przez obsesję i kompulsję uczenia się oraz związane z tym negatywne emocje) oraz czynniki będące determinantami i konsekwencjami. Wszystkie poprzednie badania wykazały, że uzależnienie od uczenia się jest pozytywnie związane z zaangażowaniem w naukę, ponieważ łączy je poświęcanie dużej ilości czasu i wysiłku (P.A. Atroszko 2015; P.A. Atroszko, B. Atroszko 2019; P.A. Atroszko, Sawicki, Kamble 2019; P.A. Atroszko et al. 2015; Lawendowski et al. 2019; Wróbel 2020). Co więcej, pogłębiona analiza związku między wymiarami zaangażowania w uczenie się a uzależnieniem od niego wykazała, że komponent absorpcji był wyraźnie związany z uzależnieniem (P.A. Atroszko, B. Atroszko 2019; Loscalzo, Giannini 2020). 
Ze względu na ten wspólny komponent niezwykle ważne jest, aby oddzielić efekty zdrowego zaangażowania i patologicznego uzależnienia, ilekroć bada się wysoki poziom wkładanego wysiłku i/lub czasu w uczenie się. Innymi słowy, konieczne jest oddzielenie negatywnych skutków uzależnienia od pozytywnych skutków zaangażowania. W przeciwnym razie wyniki badań mogą być mylące, sugerując, że zaangażowanie może mieć negatywne konsekwencje, a uzależnienie może prowadzić do pozytywnych skutków. Na przykład badania wydają się wykazywać, że uzależnienie od uczenia się może być pozytywnie powiązane z wynikami w nauce mierzonymi wyższą średnią ocen (P.A. Atroszko 2015; P.A. Atroszko et al. 2015). Gdy jednak zaangażowanie uczniów w naukę jest kontrolowane, uzależnienie od nauki zawsze wykazuje negatywny związek ze średnią lub jego brak (P.A. Atroszko 2015; P.A. Atroszko et al. 2015; Lawendowski et al. 2019; Wróbel 2020). Inny przykład dotyczy badania, które wykazało pozytywną korelację między składnikiem absorpcji zaangażowania w naukę a komponentem rywalizacji z wzorca osobowości typu A, który jest powiązany z ryzykiem chorób układu krążenia (P.A. Atroszko, B. Atroszko 2019). Związek ten nie był jednak istotny, gdy uzależnienie od uczenia się zostało uwzględnione w modelu regresji.

Obecnie, w świetle naszej wiedzy, prawie żadne z badań dotyczących zaangażowania w naukę przeprowadzonych na całym świecie nie bierze pod uwagę tego kluczowego zróżnicowania, co czyni interpretację wyników wysoce problematyczną. Poprawa procesu kształcenia młodych ludzi i rozwoju pozytywnych postaw wobec uczenia się wydaje się niemożliwa, dopóki nauczyciele, pedagodzy, psycholodzy i psychiatrzy, a także ustawodawcy nie będą rozróżniać zdrowego zaangażowania od patologicznej kompulsji uczenia się.

\section{Wnioski}

Nie ma wątpliwości, że silny nacisk na osiągnięcia edukacyjne wiąże się ze stresem uczniów i studentów oraz zaburzeniami zdrowia psychicznego. Zjawisko to odzwierciedla bardziej ogólną tendencję koncentracji na wąsko rozumianej produktywności i sukcesie ekonomicznym na poziomie całej populacji, które może skutkować nadmierną presją zarówno w środowisku pracy, jak i w systemie edukacji. Uzależnienia są ściśle związane z nieskutecznymi próbami radzenia sobie z nadmiernym stresem. Z jednej strony u wielu osób pod wpływem niepowodzeń edukacyjnych mogą rozwinąć się zaburzenia psychiczne. Z drugiej nieodpowiednie podejście w ramach systemu edukacji do takich zjawisk, jak na przykład dysleksja, ADHD czy lęk społeczny, może skutkować niepowodzeniami szkolnymi, łącznie z porzuceniem nauki, a w przyszłości z bezrobociem, niestabilnością zatrudnienia, bezdomnością i przestępczością. Tę grupę problemów można zbiorczo zaklasyfikować jako niepowodzenia w adaptacji do systemu edukacji i później do organizacji rynku pracy. Niejako osobną kategorię problemów stanowią sytuacje osób, które podejmują 
nadmierne wysiłki, dążąc do adaptacji i sukcesu w istniejącym systemie edukacji i pracy kosztem zdrowia fizycznego, psychicznego i - paradoksalnie -produktywności. Nierzadko są to osoby z ADHD, lękiem społecznym, innymi problemami zdrowia psychicznego, a także ze środowisk o niskim statusie socjoekonomicznym, co wskazuje na kompensacyjną rolę tych wysiłków. Osoby te cechuje kompulsywny stosunek do aktywności o charakterze uczenia się i pracy, konceptualizowane jako uzależnienie. Problemy te generują obecnie olbrzymie koszty indywidualne, społeczne i ekonomiczne. Praktyczną implikacją tych wniosków jest konieczność reformy systemu edukacji oraz systemu pracy (np. poprawa warunków zatrudnienia, w tym jego stabilności i odpowiedniego wynagrodzenia), nie tylko w celu redukcji ludzkiego cierpienia, ale także poprawy funkcjonowania społecznego, w tym redukcji kosztów opieki społecznej i medycznej, a także produktywności ekonomicznej. Depresja, do której prowadzi stres związany z pracą, kosztuje kraje Unii Europejskiej około 617 miliardów euro rocznie (Hassard et al. 2014: 7). To więcej niż produkt krajowy brutto Polski. Koszt samej tylko depresji w Polsce wynosi ponad 1 miliard złotych rocznie, z czego większość stanowią koszty absencji w pracy (Gałązka-Sobotka 2014). Inne koszty dotyczą między innymi chorób somatycznych (układu sercowo-naczyniowego, układu mięśniowo-szkieletowego, cukrzycy itd.), a także niewymiernych wydatków pośrednich, takich jak zaburzenia psychiczne dzieci osób doświadczających depresji, innych zaburzeń psychicznych i chorób wskutek stresu zawodowego. Dane te sugerują, że nasze rozumienie produktywności wymaga poważnej refleksji i rekonstrukcji. Pierwszym krokiem w tym kierunku może być zaakceptowanie faktu, że tak ceniona przez nas pracowitość czy pilność w nauce może mieć też negatywną stronę i być nie tylko rozwiązaniem istniejących problemów, ale też źródłem nowych.

\section{Literatura}

American Psychiatric Association, 1952, Diagnostic and statistical manual of mental disorders, Washington, DC: American Psychiatric Association.

American Psychiatric Association, 1980, Diagnostic and statistical manual of mental disorders, Washington, DC: American Psychiatric Association.

American Psychiatric Association, 2013, Diagnostic and statistical manual of mental disorders, Arlington, VA: American Psychiatric Association.

Andreassen C.S., 2014, Workaholism: An overview and current status of the research, „Journal of Behavioral Addictions" vol. 3, iss. 1.

Andreassen C.S., Griffiths M.D., Hetland J., Kravina L., Jensen F., Pallesen S., 2014, The prevalence of workaholism: A survey study in a nationally representative sample of Norwegian employees, „PloS One” vol. 9, iss. 8.

Andreassen C.S., Griffiths M.D., Sinha R., Hetland J., Pallesen S., 2016, The relationships between workaholism and symptoms of psychiatric disorders: A large-scale cross-sectional study, „PloS One” vol. 11, iss. 5. 
Andreassen C.S., Pallesen S., 2016, Workaholism: An Addiction to Work [w:] Neuropathology of drug addictions and substance misuse, ed. V.R. Preedy, London: Academic Press.

Andreassen C.S., Schaufeli W.B., Pallesen S., 2018, Myths about "The myths about work addiction" Commentary on: Ten myths about work addiction (Griffiths et al., 2018), "Journal of Behavioral Addictions" vol. 7, iss. 4.

Appleton J.J., Christenson S.L., Furlong M.J., 2008, Student engagement with school: Critical conceptual and methodological issues of the construct, „Psychology in the Schools” vol. 45 , iss. 5 .

Atroszko B., Atroszko P.A., 2013, Sytuacja materialna studentów, zaangażowanie i samoskuteczność w zakresie nauki a kompulsja uczenia się, „Przegląd Pedagogiczny” nr 2.

Atroszko P.A., 2010, Uzależnienie od pracy - wynik „słabej woli” czy potrzeby doskonałości?, „Studia Psychologica” nr 10.

Atroszko P.A., 2013, Relationship between financial resources and home environment and students' learning related attitudes, beliefs and behaviors, „Ad Alta” vol. 3, iss. 2.

Atroszko P.A., 2015, Struktura uzależnienia studentów od uczenia się: wybrane czynniki ryzyka, związek ze stresem i strategiami radzenia sobie oraz funkcjonowaniem psychospołecznym, rozprawa doktorska, Gdańsk: Uniwersytet Gdański, mps.

Atroszko P.A., 2018, Commentary on: The Bergen Study Addiction Scale: psychometric properties of the Italian version. A pilot study. Theoretical and methodological issues in the research on study addiction with relevance to the debate on conceptualising behavioural addictions, „Psychiatria i Psychologia Kliniczna” t. 18, nr 3.

Atroszko P.A., 2019a, Response to: Loscalzo and Giannini (2018). A boon of incoherence: insights on the relationship between study/work addiction and obsessive-compulsive personality disorder, „Psychiatria i Psychologia Kliniczna” t. 19, nr 2.

Atroszko P.A., 2019b, Work addiction as a behavioural addiction: Towards a valid identification of problematic behaviour, "Australian \& New Zealand Journal of Psychiatry” vol. 53, iss. 4.

Atroszko P.A., Andreassen C.S., Griffiths M.D., Pallesen S., 2015, Study addiction - a new area of psychological study: conceptualization, assessment, and preliminary empirical findings, „Journal of Behavioral Addictions” vol. 4, iss. 2.

Atroszko P.A., Andreassen C.S., Griffiths M.D., Pallesen S., 2016a, The relationship between study addiction and work addiction: A cross-cultural longitudinal study, ,Journal of Behavioral Addictions" vol. 5, iss. 4.

Atroszko P.A., Andreassen C.S., Griffiths M.D., Pallesen S., 2016b, Study addiction: A cross-cultural longitudinal study examining temporal stability and predictors of its changes, "Journal of Behavioral Addictions" vol. 5, iss. 2.

Atroszko P.A., Atroszko B., 2019, Type-A personality competitiveness component linked to increased cardiovascular risk is positively related to study addiction but not to study engagement, „Current Science” vol. 117, iss. 7.

Atroszko P.A., Atroszko B., 2020, The costs of work-addicted managers in organizations: Towards integrating clinical and organizational frameworks, "Amfiteatru Economic” vol. 22, iss. 14.

Atroszko P.A., Demetrovics Z., Griffiths M.D., 2019, Beyond the myths about work addiction: Toward a consensus on definition and trajectories for future studies on problematic overworking: A response to the commentaries on: Ten myths about work addiction (Griffiths et al., 2018), „Journal of Behavioral Addictions” vol. 8, iss. 1. 
Atroszko P.A., Demetrovics Z., Griffiths M.D., 2020, Work addiction, obsessive-compulsive personality disorder, burn-out, and global burden of disease: Implications from the ICD-11, „International Journal of Environmental Research and Public Health” vol. 17, iss. 2.

Atroszko P.A., Griffiths M.D., 2017, Work addiction is not new to the psychological literature and has evolved over time, "Global Journal of Addiction \& Rehabilitation Medicine" vol. 3 , iss. 3.

Atroszko P.A., Lawendowski R., 2020, Uzależnienie od uczenia się wśród muzyków [w:] Psychologia muzyki, red. M. Chełkowska-Zacharewicz, J. Kaleńska-Rodzaj, Warszawa: PWN.

Atroszko P.A., Mytlewska W., Atroszko B., 2020, The majority of professionally active women diagnosed with eating disorders may be at risk of work addiction: an overlooked comorbidity, „Health Psychology Report” vol. 8, iss. 1.

Atroszko P.A., Pallesen S., Griffiths M.D., Andreassen C.S., 2017, Work addiction in Poland: Adaptation of the Bergen Work Addiction Scale and relationship with psychopathology, „Health Psychology Report” vol. 5, iss. 4.

Atroszko P.A., Sawicki A., Kamble S.V., 2019, Cross-cultural pilot study on the relationship between study addiction and narcissism among undergraduate students in Poland and India, „Health Psychology Report” vol. 7, iss. 4.

Atroszko P.A., Wróbel W.K., Bereznowski P., Lawendowski R., 2019, The relationship between study addiction and examination stress among students of music academies, „Roczniki Psychologiczne" t. 22, nr 2.

Bannai A., Tamakoshi A., 2014, The association between long working hours and health: a systematic review of epidemiological evidence, „Scandinavian Journal of Work, Environment \& Health" vol. 4, iss. 1.

Bąbik A., Olejniczak D., 2014, Uwarunkowania i profilaktyka samobójstw wśród dzieci i młodzieży w Polsce, „Dziecko krzywdzone. Teoria, Badania, Praktyka” t. 13, nr 2.

Bisht A., Godiyal S., 2018, Study addiction among higher secondary students of Kendriya Vidyalaya, „Research Guru” vol. 12, iss. 3.

Bogdanowicz M., Adryjanek A., 2008, Portrety nie tylko sławnych osób z dysleksją, Gdańsk: Wydawnictwo Harmonia.

Bor W., Dean A.J., Najman J., Hayatbakhsh R., 2014, Are child and adolescent mental health problems increasing in the 21st century? A systematic review, „Australian \& New Zealand Journal of Psychiatry" vol. 48, iss. 7.

Bójko M., Maślankiewicz R., 2020, Sytuacja w polskiej psychiatrii dziecięcej na przełomie lat 2018 i 2019 na podstawie danych zebranych $w$ trybie dostępu do informacji publicznej, „Dziecko Krzywdzone. Teoria, Badania, Praktyka” t. 19, nr 1.

Chamberlain R., Brunswick N., Siev J., McManus I.C., 2018, Meta-analytic findings reveal lower means but higher variances in visuospatial ability in dyslexia, „British Journal of Psychology" vol. 109, iss. 4.

Chamberlin C.M., Zhang N., 2009, Workaholism, health, and self-acceptance, „Journal of Counseling \& Development" vol. 87, iss. 2.

Clark M.A., Michel J.S., Zhdanova L., Pui S.Y., Baltes B.B., 2016, All work and no play? A meta-analytic examination of the correlates and outcomes of workaholism, "Journal of Management" vol. 42, iss. 7.

Deci E.L., Ryan R.M., 2000, The "what" and "why" of goal pursuits: Human needs and the self-determination of behavior, „Psychological Inquiry” vol. 11, iss. 4. 
Di Stefano G., Gaudiino M., 2019, Workaholism and work engagement: How are they similar? How are they different? A systematic review and meta-analysis, „European Journal of Work and Organizational Psychology" vol. 28, iss. 3.

Gałązka-Sobotka M. (red.), 2014, Depresja - analiza kosztów ekonomicznych i społecznych, Warszawa: Uczelnia Łazarskiego.

Gilger J.W., Allen K., Castillo A., 2016, Reading disability and enhanced dynamic spatial reasoning: A review of the literature, „Brain and Cognition” vol. 105.

Goeders N.E., 2003, The impact of stress on addiction, „European Neuropsychopharmacology" vol. 13, iss. 6 .

Goldstein R.Z., Bechara A., Garavan H., Childress A.R., Paulus M.P., Volkow N.D., 2009, The neurocircuitry of impaired insight in drug addiction, „Trends in Cognitive Sciences” vol. 13 , iss. 9.

Greydanus D.E., Calles Jr J., 2007, Suicide in children and adolescents, „Primary Care: Clinics in Office Practice" vol. 34, iss. 2.

Griffiths M.D., Demetrovics Z., Atroszko P.A., 2018, Ten myths about work addiction, "Journal of Behavioral Addictions" vol. 7, iss. 4.

Gromada A., Rees G., Yekaterina Ch., 2020, Worlds of Influence: Understanding what shapes child well-being in rich countries, Florence: UNICEF Office of Research - Innocenti.

Hanson M.D., Chen E., 2007, Socioeconomic status and health behaviors in adolescence: A review of the literature, „Journal of Behavioral Medicine” vol. 30, iss. 3.

Hassard J., Teoh K., Cox T., Cosmar M., Gründler R., Flemming D., Cosemans B., van den Broek K., 2014, Calculating the cost of work-related stress and psychosocial risks. Technical Report, Luxembourg: Publications Office of the European Union.

Hiyama T., Yoshihara M., 2008, New occupational threats to Japanese physicians: Karoshi (death due to overwork) and karojisatsu (suicide due to overwork), „Occupational and Environmental Medicine" vol. 65, iss. 6.

Hoogman M., Stolte M., Baas M., Kroesbergen E., 2020, Creativity and ADHD: A review of behavioral studies, the effect of psychostimulants and neural underpinnings, „Neuroscience and Biobehavioral Reviews" vol. 119.

Hoss A.R., Styła R., Suszek H., Kowalski J., Grochowska M., Dąbrowski J., 2020, Wizerunek psychiatry, psychologa i psychoterapeuty w mediach. Analiza polskich tygodników opinii, „Psychiatria” t. 17, nr 4.

Höfer P., Rockett I.R.H., Värnik P., Etzersdorfer E., Kapusta N.D., 2012, Forty years of increasing suicide mortality in Poland: Undercounting amidst hanging epidemic?, „BMC Public Health" vol. 12, iss. 1.

Idris M.A., Dollard M.F., Winefield A.H., 2011, The effect of globalization on employee psychological health and job satisfaction in Malaysian workplaces, „Journal of Occupational Health" vol. 53, iss. 6.

Imo U.O., 2017, Burnout and psychiatric morbidity among doctors in the UK: A systematic literature review of prevalence and associated factors, „BJPsych Bulletin” vol. 41, iss. 4.

Jaggers J.W., Robison S.B., Rhodes J.L.F., Guan X., Church W.T. II, 2016, Predicting adult criminality among louisiana's urban youth: Poverty, academic risk, and delinquency, „Journal of the Society for Social Work and Research” vol. 7, iss. 1.

Jośko-Ochojska J., Lizończyk I., 2014, Występowanie depresji u młodzieży z nadwaga i otytością, „Hygeia Public Health” t. 49, nr 4. 
Katsching H., 2010, Are psychiatrists an endangered species? Observations on internal and external challenges to the profession, „World Psychiatry” vol. 9, iss. 1.

Kawecki A., 2019, Samobójstwa w Polsce - etiologia i skala zjawiska w latach 2008-2018, „Przegląd Policyjny” t. 136, nr 4.

Kazimierska A., Kinsner M., 2019, Mikrobiom a choroby cywilizacyjne, „Postępy Nauk o Zdrowiu" nr 1.

Kent K.M., Pelham W.E., Molina B.S., Sibley M.H., Waschbusch D.A., Yu J., ..., Karch K.M., 2011, The academic experience of male high school students with ADHD, "Journal of Abnormal Child Psychology" vol. 39, iss. 3.

Kieling C., Baker-Henningham H., Belfer M., Conti G., Ertem I., Omigbodun O., ... Rahman A., 2011, Child and adolescent mental health worldwide: Evidence for action, „The Lancet” vol. 378, iss. 9801.

Klinger D.A., Freeman J.G., Bilz L., Liiv K., Ramelow D., Sebok S.S. et al., 2015, Cross-national trends in perceived school pressure by gender and age from 1994 to 2010, „The European Journal of Public Health" vol. 25, iss. 2.

Klus-Stańska D., 2017, Walka o testo-maniakalne przetrwanie, czyli po co i czego ucza się przyszli nauczyciele?, „Rocznik Pedagogiczny” t. 40.

Kołodziej K., Jarek K., Murzyn M., Kuźniar J., 2020, Uwarunkowania zachowań samobójczych dzieci i młodzieży, „Pielęgniarstwo Polskie” nr 4.

Komeński J.A., 1956, Wielka dydaktyka, tłum. K. Remerowa, Wrocław: Zakład im. Ossolińskich-Wydawnictwo Polskiej Akademii Nauk.

Komisja Ekspertów przy Rzeczniku Praw Obywatelskich, 2014, Ochrona zdrowia psychicznego w Polsce: wyzwania, plany, bariery, dobre praktyki. Raport RPO, Warszawa: Biuro Rzecznika Praw Obywatelskich.

Kravina L., Falco A., De Carlo N.A., Andreassen C.S., Pallesen S., 2014, Workaholism and work engagement in the family: The relationship between parents and children as a risk factor, „European Journal of Work and Organizational Psychology” vol. 23, iss. 6.

Kwieciński Z., 1992, Socjopatologia edukacji, Warszawa: Edytor.

Kun B., 2018, Ten myths and twenty years: What we know and what we still do not know about work addiction. Commentary on: Ten myths about work addiction (Griffiths et al., 2018), „Journal of Behavioral Addictions” vol. 7, iss. 4.

Lawendowski R., Bereznowski P., Wróbel W.K., Kierzkowski M., Atroszko P.A., 2019, Study addiction among musicians: Measurement, and relationship with personality, social anxiety, performance and psychosocial functioningm, „Musicae Scientiae” vol. 24, iss. 4.

Levecque K., Anseel F., De Beuckelaer A., Van der Heyden J., Gisle L., 2017, Work organization and mental health problems in PhD students, „Research Policy” vol. 46, iss. 4.

Lichtenstein M.B., Malkenes M., Sibbersen Ch., Hinze C.J., 2019, Work addiction is associated with increased stress and reduced quality of life: Validation of the Bergen Work Addiction Scale in Danish, „Scandinavian Journal of Psychology” vol. 60, iss. 2.

Lior O., Abira R., Aviv W., 2018, Work addiction: An organizational behavior as well as an addictive behavior? Commentary on: Ten myths about work addiction (Griffiths et al., 2018), „Journal of Behavioral Addictions” vol. 7, iss. 4.

Livingston E.M., Siegel L.S., Ribary U., 2018, Developmental dyslexia: Emotional impact and consequences, „Australian Journal of Learning Difficulties” vol. 23, iss. 2.

Loscalzo Y., Giannini M., 2018a, The Bergen Study Addiction Scale: Psychometric properties of the Italian version. A pilot study, „Psychiatria i Psychologia Kliniczna” vol. 18, no 3. 
Loscalzo Y., Giannini M., 2018b, Response to: Theoretical and methodological issues in the research on study addiction with relevance to the debate on conceptualising behavioural addictions: Atroszko (2018), „Psychiatria i Psychologia Kliniczna” vol. 18, no 4.

Loscalzo Y., Giannini M., 2020, Studyholism inventory (SI-10): A short instrument for evaluating study obsession within the heavy study investment framework, „Europe's Journal of Psychology" vol. 16, iss. 4.

Luthar S.S., Becker B.E., 2002, Privileged but pressured? A study of affluent youth, „Child Development" vol. 73, iss. 5.

Makara-Studzińska M., 2013, Przyczyny prób samobójczych u młodzieży w wieku 14-18 lat, „Psychiatria” t. 10, nr 2.

Malinowska D., 2018, How to counter the ten myths about work addiction?: Three postulates for future research Commentary on: Ten myths about work addiction (Griffiths et al., 2018), „Journal of Behavioral Addictions” vol. 7, iss. 4.

Marmet S., Studer J., Lemoine M., Grazioli V.S., Bertholet N., Gmel G., 2019, Reconsidering the associations between self-reported alcohol use disorder and mental health problems in the light of co-occurring addictions in young Swiss men, „PloS One” vol. 14, iss. 9.

Melosik Z., 2016, Wskaźnikowanie człowieka i rzeczywistości jako forma sprawowania władzy, „Przegląd Pedagogiczny” nr 2.

Mishra N., Shrestha D., Poudyal R., Mishra P., 2013, Retrospective study of suicide among children and young adults, „Journal of Nepal Paediatric Society” vol. 33, iss. 2.

Moskalewicz J., Kiejna A., Wojtyniak B. (red.), 2012, Kondycja psychiczna mieszkańców Polski. Raport z badań „Epidemiologia zaburzeń psychiatrycznych i dostęp do psychiatrycznej opieki zdrowotnej - EZOP Polska”, Warszawa: Instytut Psychiatrii i Neurologii.

Murawiec S., 2020, Sprawozdanie Rzecznika Prasowego Polskiego Towarzystwa Psychiatrycznego kadencji 2016-2019, „Psychiatria” t. 17, nr 1.

Najwyższa Izba Kontroli, 2020, Dostępność lecznictwa psychiatrycznego dla dzieci i młodzieży (w latach 2017-2019), Warszawa, https://www.nik.gov.pl/plik/id,22730,vp,25429.pdf [dostęp: 13.12.2020].

Namysłowska I., 2013, Zdrowie psychiczne dzieci i młodzieży w Polsce - stanrozwoju opieki psychiatrycznej i zadania na przyszłość, „Postępy Nauk Medycznych” t. 26, nr 1.

Napieralska E., Kułaga Z., Gurzkowska B., Grajda A., 2010, Epidemiologia zgonów dzieci i młodzieży z powodu samobójstw w Polsce w latach 1999-2006, „Problemy Higieny i Epidemiologii" t. 91, nr 1.

Nature, 2019, The mental health of PhD researchers demands urgent attention, „Nature” vol. 575.

The New York Times, June 8, 1900, William T. Parker Dead.; Became Suddenly Insane at the Harvard Law School Examinations, https://www.nytimes.com/1900/06/08/archives/william-t-parker-dead-became-suddenly-insane-at-the-harvard-law.html [dostęp: 17.03.2021].

Ogińska-Bulik N., Zadworna-Cieślak M., 2014, Rola prężności psychicznej w radzeniu sobie ze stresem związanym z egzaminem maturalnym, „Przegląd Badań Edukacyjnych” nr 19.

Ogólnopolski Związek Zawodowy Lekarzy, 2017, Oświadczenie OZZL w sprawie kolejnych przypadków śmierci lekarzy na dyżurach, http://www.ozzl.org.pl/index.php/ 13720-oswiadczenie-ozzl-w-sprawie-kolejnych-przypadkow-smierci-lekarzy-na-dyzurach [dostęp: 16.03.2021]. 
O’Neil A., Quirk S.E., Housden S., Brennan S.L., Williams L.J., Pasco J.A., ..., Jacka F.N., 2014, Relationship between diet and mental health in children and adolescents: a systematic review, „American Journal of Public Health” vol. 104, iss. 10.

Orosz G., Dombi E., Andreassen C.S., Griffiths M.D., Demetrovics Z., 2016, Analyzing models of work addiction: Single factor and bi-factor models of the Bergen Work Addiction Scale, „International Journal of Mental Health and Addiction” vol. 14, iss. 5.

Panagioti M., Panagopoulou E., Bower P., Lewith G., Kontopantelis E., Chew-Graham C., ..., Esmail A., 2017, Controlled interventions to reduce burnout in physicians: A systematic review and meta-analysis, „JAMA Internal Medicine” vol. 177, iss. 2.

Pardej K., 2016, Skutki niepowodzeń edukacyjnych uczniów szkół zawodowych, „Rozprawy Społeczne" t. 10, nr 2.

Patel A., Knapp M., Henderson J., Baldwin D., 2002, The economic consequences of social phobia, „Journal of Affective Disorders” vol. 68, iss. 2-3.

Polok G., Szromek A.R., Krannich M., Wybrańczyk K., 2018, Wpływ uzależnienia od pracy zawodowej, rozpadu rodziny oraz alkoholizmu na wspótistniejące zachowania wśród osób do 35 roku życia, „Zeszyty Naukowe. Organizacja i Zarządzanie/Politechnika Śląska” z. 131.

Quinones C., 2018, Moving from the terminology debate to a transdisciplinary understanding of the problem Commentary on: Ten myths about work addiction (Griffiths et al., 2018), "Journal of Behavioral Addictions" vol. 7, iss. 4.

Quinones C., Griffiths M.D., 2015, Addiction to work: A critical review of the workaholism construct and recommendations for assessment, „Journal of Psychosocial Nursing and Mental Health Services" vol. 53, iss. 10.

Richardson A.S., Bergen H.A., Martin G., Roeger L., Allison S., 2005, Perceived academic performance as an indicator of risk of attempted suicide in young adolescents, „Archives of Suicide Research" vol. 9, iss. 2.

Robinson B.E., 1999, The Work Addiction Risk Test: Development of a tentative measure of workaholism, „Perceptual and Motor Skills” vol. 88, iss. 1.

Robinson B.E., 2014, Chained to the desk: A guidebook for workaholics, their partners and children, and the clinicians who treat them, New York: NYU Press.

Rocque M., Snellings Q., 2018, The new disciplinology: Research, theory, and remaining puzzles on the school-to-prison pipeline, "Journal of Criminal Justice” vol. 59.

Salvagioni D.A.J., Melanda F.N., Mesas A.E., González A.D., Gabani F.L., Andrade, S.M.D., 2017, Physical, psychological and occupational consequences of job burnout: A systematic review of prospective studies, „PloS One” vol. 12, iss. 10.

Schaufeli W.B., Martinez I.M., Pinto A.M., Salanova M., Bakker A.B., 2002, Burnout and engagement in university students: A cross-national study, „Journal of Cross-Cultural Psychology" vol. 33, iss. 5.

Schaufeli W.B., Salanova M., González-Romá V., Bakker A.B., 2002, The measurement of engagement and burnout: A two sample confirmatory factor analytic approach, „Journal of Happiness Studies" vol. 3, iss. 1.

Sekcja Ochrony Zdrowia Narodowej Rady Rozwoju, 2016, Rekomendacje dla Ministerstwa Zdrowia po spotkaniu Sekcji Ochrony Zdrowia z 9 lutego 2016 r. na temat zdrowia psychicznego, https://www.prezydent.pl/kancelaria/nrr/aktualnosci/art,26,sekcja-ochrony-zdrowia-nrr-przedstawila-rekomendacje-na-temat-zdrowia-psychicznego.html [dostęp: 13.12.2020]. 
Shimazu A., Bakker A.B., Demerouti E., Fujiwara T., Iwata N., Shimada K., Takahashi M., Tokita M., Watai I., Kawakami N., 2020, Workaholism, Work Engagement and Child Well-Being: A Test of the Spillover-Crossover Model, „International Journal of Environmental Research and Public Health" vol. 17, iss. 17.

Sikora R., 2010, Stres szkolny u dzieci rozpoczynajacych nauke w klasie czwartej, „Forum Oświatowe" t. 22, nr 2.

Sinha R., 2007, The role of stress in addiction relapse, „Current Psychiatry Reports” vol. 9, iss. 5. Spence J.T., Robbins A.S., 1992, Workaholism: Definition, measurement, and preliminary results, „Journal of Personality Assessment” vol. 58, iss. 1.

Stein M.B., Kean Y.M., 2000, Disability and quality of life in social phobia: Epidemiologic findings, „American Journal of Psychiatry” vol. 157, iss. 10.

Supranowicz P., Wysocki M.J., 2010, Stres szkolny a zaburzenia zdrowia młodzieży gimnazjalnej, „Roczniki Państwowego Zakładu Higieny” t. 61, nr 2.

Sussman S., 2012, Workaholism: A review, „Journal of Addiction Research \& Therapy”, suppl. 6(1), 4120.

Sussman S., 2018, Ten myths (or facts?) about workaholism: An appetitive motivation framework. Commentary on: Ten myths about work addiction (Griffiths et al., 2018), „Journal of Behavioral Addictions" vol. 7, iss. 4.

Sussman S., Arpawong T.E., Sun P., Tsai J., Rohrbach L.A., Spruijt-Metz D., 2014, Prevalence and co-occurrence of addictive behaviors among former alternative high school youth, „Journal of Behavioral Addictions” vol. 3, iss. 1.

Sussman S., Pokhrel P., Sun P., Rohrbach L.A., Spruijt-Metz D., 2015, Prevalence and co-occurrence of addictive behaviors among former alternative high school youth: A longitudinal follow-up study, „Journal of Behavioral Addictions” vol. 4, iss. 3.

Szkudlarek T., 2005, Ekonomia i społeczne skutki reform oświatowych [w:] Holistyczne i analityczne metody diagnostyki edukacyjnej. Perspektywy informatyczne egzaminów szkolnych, red. B. Niemierko, G. Szyling, Gdańsk: Fundacja Rozwoju Uniwersytetu Gdańskiego.

Śliwerski B., Kobierski K., 2008, Rzecz o edukacyjnym kłamstwie, „Annales. Etyka w życiu gospodarczym" t. 11, nr 2.

Tabak I., 2014, Zdrowie psychiczne dzieci i młodzieży. Wsparcie dzieci i młodzieży w pokonywaniu problemów, „Studia BAS” nr 2.

Talik E., 2011, Specyfika stresu szkolnego i strategie radzenia sobie $z$ nim przez młodzież w okresie dorastania, „Horyzonty Psychologii i Nauk o Człowieku” t. 1, nr 1.

Tavolacci M.P., Ladner J., Grigioni S., Richard L., Villet H., Dechelotte P., 2013, Prevalence and association of perceived stress, substance use and behavioral addictions: a cross-sectional study among university students in France, 2009-2011, „BMC Public Health vol. 13, iss. 1.

Tawfik D.S., Profit J., Morgenthaler T.I., Satele D.V., Sinsky C.A., Dyrbye L.N., Tutty M.A., West C.P., Shanafelt T.D., 2018, Physician burnout, well-being, and work unit safety grades in relationship to reported medical errors, „Mayo Clinic Proceedings” vol. 93, iss. 11.

Tóth-Király I., Böthe B., Orosz G., 2018, Seeing the forest through different trees: A social psychological perspective of work addiction: Commentary on: Ten myths about work addiction (Griffiths et al., 2018), „Journal of Behavioral Addictions” vol. 7, iss. 4.

Tsai J., Huh J., Idrisov B., Galimov A., Espada J.P., Gonzálvez M.T., Sussman S., 2016, Prevalence and co-occurrence of addictive behaviors among Russian and Spanish youth: A replication study, „Journal of Drug Education” vol. 46, iss. 1-2. 
Tsui A.H., 2008, Asian wellness in decline: A cost of rising prosperity, „International Journal of Workplace Health Management" vol. 1, iss. 2.

Uehata T., 2005, Karoshi, death by overwork, „Nihon rinsho. Japanese Journal of Clinical Medicine" vol. 63, iss. 7.

Vallerand R.J., 2015, The psychology of passion: A dualistic model, New York, NY: Oxford University Press.

Villella C., Martinotti G., Di Nicola M., Cassano M., La Torre G., Gliubizzi M.D.,... Conte G., 2011, Behavioural addictions in adolescents and young adults: Results from a prevalence study, „Journal of Gambling Studies” vol. 27, iss. 2.

Virtanen M., Heikkilä K., Jokela M., Ferrie J.E., Batty G.D., Vahtera J., Kivimäki M., 2012, Long working hours and coronary heart disease: A systematic review and meta-analysis, „American Journal of Epidemiology” vol. 176, iss. 7.

Wakefield J.C., 2007, The concept of mental disorder: Diagnostic implications of the harmful dysfunction analysis, „World Psychiatry” vol. 6, iss. 3 .

Walburg V., 2014, Burnout among high school students: A literature review, „Children and Youth Services Review" vol. 42.

Walkiewicz M., Sowińska K., Tartas M., 2014, Wypalenie zawodowe wśród personelu medycznego - przegląd literatury, „Przegląd Lekarski” t. 71, nr 5.

West C.P., Dyrbye L.N., Erwin P.J., Shanafelt T.D., 2016, Interventions to prevent and reduce physician burnout: A systematic review and meta-analysis, „The Lancet” vol. 388, iss. 10057.

Wise M.L., Wise B.L., Jones S.R., 2019, The maladaptive coping cycle: A model for understanding academic and social failure in children with ADHD, "The ADHD Report” vol. 27, iss. 7.

World Health Organization, 2005, European strategy for child and adolescent health and development, EURO/05/5048378, Copenhagen: WHO Regional Office for Europe,.

World Health Organization, 2019, International statistical classification of diseases and related health problems, 11th Revision, Beta Draft, ICD 11, https://icd.who.int/browse11/1-m/en [dostęp: 2.06.2020].

Wróbel W.K., 2020, Study addiction among high school students: Measurement and relationship with psychopathology, personality, quality of life, and school variables, praca magisterska, Gdańsk: Uniwersytet Gdański, mps.

Zeng K., Le Tendre G., 1998, Adolescent suicide and academic competition in East Asia, „Comparative Education Review" vol. 42, iss. 4.

Ziółkowska A.M., 2020, Samobójstwa dzieci i młodzieży przed wybuchem II wojny światowej i obecnie - co się zmieniło, co pozostało bez zmian, „Nowa Kodyfikacja Prawa Karnego” t. 55 .

\section{Streszczenie}

W artykule przedstawiono związki łączące presję na osiągnięcia szkolne i akademickie, odczuwaną przez uczniów i studentów, z rozwojem uzależnienia od uczenia się, uzależnienia od pracy oraz innych zaburzeń psychicznych i wzrostu częstotliwości występowania zjawisk z obszaru psychopatologii (np. samobójstw). Przeanalizowano aktualny stan wiedzy na temat uzależnienia od pracy oraz od uczenia się, a także omówiono podobieństwa i różnice między zaangażowaniem w daną aktywność (pracę lub naukę) a uzależnieniem 
od niej. W szczególności przedstawiono teoretyczne i praktyczne znaczenie konceptualizacji problemów pogarszającego się stanu zdrowia psychicznego młodego pokolenia w kategoriach uzależnienia od pracy i uczenia się, a także ich związku z obsesją sukcesu socjoekonomicznego.

\section{Słowa kluczowe}

presja edukacyjna, psychopatologia, stres szkolny, uzależnienie od pracy, uzależnienie od uczenia się

\section{Summary \\ Educational pressure and the development of study addiction, work addiction and other disorders}

The article presents the relationships between the pressure on school and academic achievements felt by pupils and students with the development of study addiction, work addiction and the progression of other mental disorders and phenomena from the area of psychopathology (such as suicide). The current state of knowledge on work addiction and study addiction was analyzed, and the similarities and differences between engagement in an activity (work or study) and addiction to this activity were discussed. In particular, the theoretical and practical importance of the conceptualization of the problems of the deteriorating mental health of the young generation in terms of addiction to work and study, as well as their relation to the obsession with socioeconomic success was presented.

\section{Keywords}

educational pressure, psychopathology, school stress, study addiction, work addiction 